\title{
T30 - Análisis de redes sociales para la comunicación entre organizaciones de gestión de desastres en Panamá
}

\author{
Xiomara Vallarino \\ Universidad Marítima Internacional de Panamá, Panamá
}

*Autor al que se dirige la correspondencia: jcasas@umip.ac.pa

\section{Resumen}

$\mathrm{E}$ n la última década, se reportaron más de 4,014 desastres naturales de acuerdo al Informe Mundial sobre Desastres 2010. Panamá, a pesar que no ha sufrido desastres de grandes magnitudes, es parte de estas estadísticas: en los años 2010 y 2011 se registraron inundaciones en las provincias de Bocas del Toro, Colón, Darién, Chiriquí y en las regiones de Panamá Este y Oeste, reportándose un número mayor de 32,900 afectados. Es por ello que con este estudio buscamos diagnosticar la situación actual de los patrones de comunicación y coordinación de las acciones para la asistencia humanitaria y brindar una propuesta para un Sistema de Redes para la Comunicación y Coordinación de las Organizaciones de Logística Humanitaria y Gestión de Desastre en Panamá. Para lograr el objetivo utilizamos la metodología de Análisis de Redes Sociales (ARS) para medir las relaciones o vínculos existentes entre los actores que forman parte del sistema de logística humanitaria y gestión de riesgo de desastre, y de esta manera, identificar los patrones de comunicación y coordinación. Una vez estos identificados estos patrones se hizó una propuesta para mejorar las relaciones y aumentar los niveles de conectividad de la red de organizaciones tomando en consideración parámetros de diferentes instituciones internacionales y lograr que la comunicación y la coordinación entre las instituciones sea más dinámica y continua para que las acciones fortalezcan la capacidad local de brindar asistencia humanitaria a las poblaciones afectadas.

Palabras claves: logística humanitaria, gestión de riesgos, coordinación, análisis de redes sociales

\begin{abstract}
I n the last decade, more than 4,014 natural disasters were report according to the World Disasters Report 2010. Although, Panama has not suffered disasters of great magnitude it is part of these statistics; in 2010 and 2011 floods were registered in the provinces of Bocas del Toro, Colon, Darien, Chiriquí and in the regions of East and West of Panama, being reported a number grater than 32,900 affected. For those reasons, the purpose of this study is to provide a diagnosis of the current situation of the patterns of communication and coordination to provide humanitarian assistance and present a proposal for a system for communication and coordination network for the organizations of Humanitarian Logistics and Disaster Management in Panama. To achieve our objective we use the methodology of social network analysis (SNA) to measure the relationships or links between actors who are part of the system of humanitarian logistics and disaster risk management and identify the patterns of communication and coordination. Once patterns of communication and coordination were identify, a proposal was made in order to improve relations and increase levels of connectivity of the network of organizations, taking into account parameters of different international institutions and make communication and coordination between institutions more dynamic and continuous, also to strengthen local capacity to provide humanitarian assistance to affected populations.
\end{abstract}

Keywords: humanitarian logistics, risk management, social network analysis, Panama 